\title{
Empirical Study on the Computer-aided College English Translation Teaching
}

\author{
https://doi.org/10.3991/ijet.v11i12.6012 \\ Wang Bin \\ Huaibei Normal University, Huaibei, China
}

\begin{abstract}
This paper aims at analyzing how to improve College English translation teaching with the aid of the computer. The research objects are 80 non-English major students from two classes of a local university in China. Based on the changes of translating abilities of the two groups in a semester and interviews, the author comparatively analyzes the influences of the computer aid on College English translation teaching. The main findings of this research can be listed as follows: there exist problems with students' using the computer to improve their translating ability; students can be taught to use the computer to improve translating; the use of computer can effectively help students improve their translating ability.
\end{abstract}

Index Terms-Computer-aided translation, Translation ability, Translation teaching

\section{INTRODUCTION}

To develop students' translating ability is one of the key teaching aims of College English course. As for students' translation ability, according to College English Curriculum Requirements published by Ministry of Education of the People's Republic of China (MOE) in 2014, the general requirements (the basic requirements that non-English major college or university students should meet) are that: students can accomplish the translation of articles whose subjects are familiar to students with the help of dictionaries at the speed of 300 English words per hour when doing English-Chinese translation and 250 words per hour when doing Chinese-English translation; the translation should be fluent basically and students can make proper use of some translation strategies. In CET4 (College English Test Band 4) and CET6 (College English Test Band 6), which are the most important tests to test Chinese college students' English competence, more attention has been paid to translation. From the December of 2013, CET4 and CET6 adjusted sentence translation to paragraph translation, with the degree of difficulty from 0.89 to 0.95 and the score from 5 to 15 . According to the test results of CET4 and CET6 in recent years, students' translation ability is far below expectations. So, how to efficiently improve students' translation ability has been one of the key problems to be solved in College English teaching, and it has become one of the key research issues in the academic circles of the second language acquisition (SLA) in China. When the author input College English Translation Teaching as the title in China National Knowledge Infrastructure (CNKI), 1028 papers could be retrieved, 92 of which have been published in Chinese core journals. Focuses of attention to College English translation teaching from the academic circles can be mainly demonstrated as follows: the main reasons for the problems that have arisen in the translation of non-English major college or university students or the reasons why non-English major college or university students are weak in translation(Chen Aiming \& Niu Jiezhen ${ }^{[1]}$, Wu Shuli ${ }^{[2])}$; the main problems that have arisen in the translation of non-English major college or university students or in the college English translation teaching. (Wang Liya ${ }^{[3]}$, Yang Ruiling ${ }^{[4]}$, Zhang Ling [5], Wang Zhuo ${ }^{[6])}$; the ways to improve college English translation teaching. Li Zhonghua analyses the countermeasures from the following points: the marginal status of college English translation teaching should be changed, each area and each college or university should make its own syllabus according to the actual situation to guide college English translation teaching considering that there is no national syllabus for college English translation teaching, and there should be qualified teachers who can achieve the teaching aims and teaching tasks stipulated in the syllabus ${ }^{[7]}$. Cai Jigang holds that teachers should teach the non-English major students translation skills and the college or university should run the course of translation teaching so as to improve the

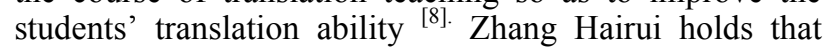
colleges and universities should improve the teaching syllabus of college English, reform the content of teaching materials, change the teaching mode and strengthen teaching staff construction so as to make college English translation teaching step onto a new level and cultivate translation talents who can adapt to the development of society and economy ${ }^{[9]}$. From the above description, we may easily find that the scholars have deeply thought about how to solve the problem that non-English major students are weak in translation from teaching and learning by combining macro and micro. Their research results are of great value for us to solve the problem. However, it is regrettable that few scholars have discussed how to improve the college English translation teaching from the angle of the computer aid although the computer has become an indispensable part in our teaching and life and translation software provided by many companies has been widely used. In light of that, the author of this paper plans to discuss how to improve college English translation teaching with the aid of the computer.

\section{THEORATICAL BASIS}

To improve students' translating ability with the aid of the computer, students' explorative and cooperative learning is of great importance. When we discuss students' explorative and cooperative learning with the aid of the computer, constructivism which has made solid foundation for computer-aided translation should be mentioned. Constructivism is considered to be one of the most promising learning theories. The early learning theories enthroned the behaviorism school. Behaviorists hold that the 
educator's target is to spread the knowledge in the objective world, and the task of the learner is to achieve the target set by the educator in the course of spreading knowledge ${ }^{[10] .}$ However, the behaviorism school neglected the students' mental process in the course of knowledge spreading. More and more people know the disadvantages of this kind of deficiency. By the 1960s, the cognitive school had taken the leading place of behaviorism school. Different from the behaviorism, cognitivism thinks highly of the internal cognitive process and pays attention to how the knowledge is processed and understood. With the development of cognitive theories, constructivism, as a branch of cognitivism, emerged. Constructivism lays more emphasis on the subjective understanding of the learners and pays more attention to the establishment of the learner's initiative to explore the knowledge of the situation ${ }^{[11]}$. J. Piaget (1896-1980), a Switzerland psychologist, is one of the important pioneers of modern constructivism. With the continued efforts of other psychologists and educators like Ausubel, Bruner and Vygotsky, constructivism has been developed and enriched. In the 1980s, it started to be applied to teaching. Nonetheless, due to the objective conditions, it didn't produce great influences on the actual teaching activities. Recently, as internet-based communication technology and multimedia computers have been used more and more widely, constructivism has begun to catch widespread attention (Carwile, Julie ${ }^{[12]}$, D. Scott Brandt ${ }^{[13]}$, Barney Dalgarno $\left.{ }^{[14]}\right)$. According to constructivism, learning is the process of obtaining knowledge, and in certain circumstance, linguistic knowledge can be acquired through the process of meaning construction with the help of other persons and some necessary learning materials. The core of constructivism theory is that students are knowledge constructors, who are self controlled. The central task of the teaching practice is to help students improve their cognitive abilities. To achieve this purpose, educators should provide a good environment for the students to help them independently or collectively create their own opinions ${ }^{[15]}$. Constructivism is viewed to have brought about a great revolution in modern education, which has been aided by the fast development of the multimedia network technology. It is also viewed as the most significant theoretical basis for language learning and translation teaching in the computer-based network circumstance. Under the guidance of constructivism, CATT (computer-aided translation teaching) will accomplish the aim to improve students' translation abilities effectively.

\section{RESEARCH DESIGN}

\section{A. Research problems}

This research aims at surveying how to improve nonEnglish major students' translation ability with the aid of the computer. In detail, the research questions can be listed as follows:

1. Do problems about students' using computer to improve their translating ability exist?

2. Can using the computer to improve translating be taught?

3. Can the use of computer effectively help students improve their translating ability?

\section{B. Research objects}

We randomly selected 80 non-English major sophomores from two classes from different schools at a normal university in Anhui province. 40 students from the first class were assigned to be the experimental group, and the other 40 students from the second class were assigned to be the control group. At the beginning of the semester and at the end of the semester, the two groups were given two translation assignments. After the first assignment, students from the experimental group were taught how to use the computer to improve their translation while students from the second group were not. The two assignments were checked by the same software-www.pigai.org. According to the checking results, we can observe obvious differences of the average scores of the experimental group. However, no obvious differences can be found in the average scores of the control group.

\section{Research tools}

The main research tools are two translation tasks of CET4. Each test time is 15 minutes, and during the tests, students can use the computer to finish the test. In order to make the statistics easy, after each test, students are given 5 minutes to underline the words and sentences which have been translated with the aid of the computer. In order to prevent the phenomenon that some students are too careless or nervous to underline certain words or sentences translated with the aid of the computer, after the second test, the author did separate retrospective interviews. In the interview, the author asked some questions about the words and sentences which were not easy to translate for them and how they dealt with them with the aid of the computer.

\section{Research process}

In the experimental class, the author adopted the computer-aided teaching mode. The students were taught to use some common translation software and some search engine, like Baidu translation, Youdao translation and Kingsoft, to make the words properly used and make the sentence structure proper in the translation and were given some assignments to practice translating with the aid of the computer. In the control class, the author adopted the traditional teaching mode. In class, the author gave the account of translation knowledge, gave translation assignment, and gave comments after checking the translation assignment. At the end of the semester, the author gave students from two classes the same assignment and asked the experimental class students to fill out a questionnaire about their satisfaction degree towards translation with the aid of the computer. The author analyzed the two classes' variations in the two test results and the questionnaire result.

\section{RESEARCH RESULTS AND DisCUSSION}

\section{A. Problems in the translation with the aid of the computer}

In order to understand the problems that arise when students use the computer to translate, the author conducted the statistics of the usage of the computer to finish the translation in the first test in Table I. From the table, we can see that when allowed to use the computer to finish the translation, the students mainly use the computer to 
look up the words from the computer (in the experimental group, every student uses this strategy 3.2 times on average, and in the control group, every student uses this strategy 2.7 times on average), and only $49 \%$ of the words chosen from the internet by the experimental group are correct; only $45 \%$ of the words chosen from the internet by the control group are correct (their main mistakes lie in that they don't know the part of speech of some words and can't distinguish some easily mixed words). However, few students from both the experimental group and the control group used the computer to finish the sentence translation (in the experimental group, every student uses this strategy 0.4 times on average, and in the control group, every student uses this strategy 0.3 times on average), and only $35 \%$ of the sentences by the experimental group are correct; only $33 \%$ of the sentences by the control group are correct (the main reason is that they don't believe the software can give accurate sentence structure and their own grammar knowledge is not so good). The statistics in TABLE I shows that when students use the computer to translate, their strategies of translating both words and sentences need improving.

\section{B. Techability of using the computer to improve translation}

In order to help the students make better use of the computer to improve their translation, after the first test, the author gave the students some specific advice on how to use the internet to improve their translation combining scoring criteria of CET4 and the problems in the first test. As for the words difficult to translate, the author emphasized that after looking up the word on the internet, the students should figure out the part of speech of the word and distinguish some easily mixed words with the help of the internet. As for the accuracy of the sentence structure, the author emphasized that students should figure out the sentence structure and should try to find some bilingual sentences to help them with the help of the computer. Every two weeks, students in the experimental group were given a translation assignment to practice using the above strategies to improve their translation. At the end of the semester, the author gave the students another assignment. The author compared and analyzed the usage of using the computer to improve the translation of the experimental group in Table II. From the table, we can see that both the using frequency and the accuracy have been greatly improved. The times of students using the computer to translate the words rose from 128 to 231 , with the accuracy rising from $37 \%$ to $65 \%$. The times of students using the computer to translate the sentences rose from 17 to 82 , with the accuracy rising from $35 \%$ to $63 \%$. The statistics show that the strategies of using the computer to translate are teachable.

\section{The relationship between computer-aided translation training and students' translating ability}

In order to survey whether students' translation ability can be improved through computer-aided translation strategy training, the author compared and analyzed the score changes of the two groups in the two tests in Table III.

Table III shows that after the computer-aided translation strategy training for a semester, the students from the experimental group have greatly improved their translation ability. Their average score increased by $44 \%$, while the average score of the control group only increased by
TABLE I.

USAGE OF THE COMPUTER TO FINISH THE TRANSLATION

\begin{tabular}{|c|c|c|c|}
\hline & & \begin{tabular}{|c|} 
Times of using \\
the internet to \\
finish the transla- \\
tion \\
\end{tabular} & $\begin{array}{c}\text { Times of correct } \\
\text { translation with } \\
\text { the help of the } \\
\text { internet }\end{array}$ \\
\hline \multirow{2}{*}{$\begin{array}{l}\text { The experi- } \\
\text { mental group }\end{array}$} & words & 128 & 60 \\
\hline & sentences & 17 & 6 \\
\hline \multirow{2}{*}{$\begin{array}{l}\text { The control } \\
\text { group }\end{array}$} & words & 108 & 49 \\
\hline & sentences & 12 & 4 \\
\hline
\end{tabular}

TABLE II.

COMPARISON BETWEEN USAGES OF THE COMPUTER TO FINISH THE TRANSLATION IN TWO TESTS OF THE EXPERIMENTAL GROUP

\begin{tabular}{l|l|c|c}
\hline \multicolumn{2}{c|}{} & $\begin{array}{c}\text { Times of using the } \\
\text { internet to finish } \\
\text { the translation }\end{array}$ & $\begin{array}{c}\text { Times of correct } \\
\text { translation with the } \\
\text { help of the internet }\end{array}$ \\
\hline \multirow{2}{*}{ Test 1} & words & 128 & 47 \\
\cline { 2 - 4 } & sentences & 17 & 6 \\
\hline \multirow{2}{*}{ Test 2 } & words & 231 & 151 \\
\cline { 2 - 4 } & sentences & 82 & 52 \\
\hline
\end{tabular}

TABLE III.

COMPARISON OF THE AVERAGE SCORES OF THE EXPERIMENTAL GROUP AND THE CONTROL GROUP

\begin{tabular}{l|c|c}
\hline & Test1 & Test2 \\
\hline $\begin{array}{l}\text { Average score of the experimental } \\
\text { group }\end{array}$ & 6.3 & 9.1 \\
\hline Average score of the control group & 6.6 & 7.1 \\
\hline
\end{tabular}

$7.5 \%$. The interview for the students from the experimental group after the second test confirmed that their translation ability had been greatly improved mainly because computer-aided translation strategy training really had helped them a lot not because they spend more time on translation in their daily learning.

\section{CONCLUSION}

This research surveys the problems that arise when nonEnglish major students use the computer to translate and the teachability of the strategies to use the computer to translate, and analyzes the relationship between computeraided translation strategy training and the students' translation ability. The research finds that when students use the computer to translate, their strategies are not scientific. The problems mainly lie in that they don't know the part of speech of some words; they can't distinguish some easily mixed words and few of them use the internet to help them analyze sentence structure accurately even though their own grammar knowledge is not so good. But after the teaching and practice of relevant strategies, the above situation has been greatly improved and the students' translation ability and average score have also increased correspondingly.

This research introduces computer-aid into the college English translation teaching. Based on the previous research, this research classifies the problems that arise when students use the computer to translate and analyzes how to deal with the problems so as to help students improve their translation ability. This research is of great methodological significance for college English translation teaching and the improvement of students' translation ability. 


\section{SHORT PAPER \\ EMPIRICAL STUdy ON THE COMPUTER-AIDED COLLEGE ENGLISH TRANSLATION TEACHING}

\section{REFERENCES}

[1] Chen Aiming, Niu Jiezhen, "Researches on how to improve translating abilities of non English major students" (in Chinese), Overseas English, vol. 17, no, 5, pp.54-59, 2015.

[2] Wu Shuli, "A look at college English teaching from non-English major students' weak translation ability” (in Chinese), Chinese Translators Journal, vol.23, no, 3, pp.59-60, 2010.

[3] Wang Liya, "Researches on strategies and problems in college English translation teaching" (in Chinese), Journal of Lanzhou Institute of Education, vol.32, no, 11, pp.127-131, 2015.

[4] Yang Ruiling, "Analyses on strategies and current situations of College English translation teaching" (in Chinese), The Journal of Shandong Agriculture and Engineering University, vol. 32, no, 2, pp.15-16, 2016.

[5] Zhang Ling, "Survey reports about the problems in the college English translation teaching" (in Chinese), Shanghai Journal of Translators for Science and Technology, vol. 15, no, 3, pp.46-49, 2000 .

[6] Wang Zhuo, "Problems and strategies in college English teaching and learning" (in Chinese), Education Exploration, vol. 32, no, 5, pp.59-60, 2012.

[7] Li Zhonghua, "College English translation teaching: the present situations and countermeasures" (in Chinese), Foreign Languages and Their Teaching, vol. 29, no, 9, pp.47-49, 2007.

[8] Cai Jigang, "College English translation teaching should be taken seriously so as to improve the students' application ability" (in Chinese), Chinese Translators Journal, vol. 24, no, 1, pp.63-66, 2003.
[9] Zhang Hairui, "Problems and strategies in college English translation teaching" (in Chinese), Theory and Practice of Education, vol. 30, no, 19, pp.62-64, 2010.

[10] Chen Kuiyang, "On translation class teaching from the perspectives of constructivism" (in Chinese), Chinese Translators Journal, vol. 26, no, 3, pp.78-81, 2005.

[11] Zhang Weimin, "Constructivism and teaching design principles" (in Chinese), Media in Foreign Language Instruction, vol. 21, no, 3, pp.23-26, 2000.

[12] Carwile, Julie, "A constructivist approach to online teaching and learning”, Inquiry, Vol.12 No.1 P68-73, 2007.

[13] D. Scott Brandt, "Constructivism: teaching for understanding of the Internet", Communications of the Association for Computing $\begin{array}{llll}\text { Machinery, } & \text { Vol.40 No.10 P112-117, } & 1997 .\end{array}$ https://doi.org/10.1145/262793.262814

[14] Barney Dalgarno, "Interpretations of constructivism and consequences for Computer Assisted Learning", British Journal of Educational Technology, Vol.32 NO.2 P183-194, 2001. https://doi.org/10.1111/1467-8535.00189

[15] Dong Wei, \& Fu Lixu, "Survey on the college English multimedia network classroom under the guidance of constructivism" (in Chinese), Foreign Language World, vol. 24, no, 2, pp.8-13, 2004.

\section{AUTHOR}

Wang Bin is with Huaibei Normal University, Huaibei 235000 China (e-mail: wang-bin2003@126.com ).

Submitted 04 July 2016. Published as resubmitted by the author 13 September 2016. 